\title{
IDENTIFIKASI KARAKTERISTIK JAKARTA ISLAMIC INDEX DENGAN MENGGUNAKAN ALGORITMA K-MEANS
}

\author{
Liga Mayola ${ }^{1)}$, Sigit Sanjaya ${ }^{2)}$, dan Wifra Safitri ${ }^{3)}$ \\ ${ }^{1,3}$ Sistem Informasi, Fakultas Ilmu Komputer, Universitas Putra Indonesia YPTK \\ ${ }^{2}$ Akuntansi, Fakultas Ekonomi dan Bisnis, Universitas Putra Indonesia YPTK \\ $1,2,3$ Jl. Raya Lubuk Begalung, Padang, 25125 \\ ligamayola@upiyptk.ac.id ${ }^{1)}$, sigitsanjaya@ upiyptk.ac.id ${ }^{2)}$, wifrasafitri@upiyptk.ac.id ${ }^{3)}$
}

\begin{abstract}
ABSTRAK
Investor memerlukan informasi pergerakan harga saham dan variabel ekonomi yang mempengaruhi naik-turunnya harga saham. Penelitian ini bertujuan mengidentifikasi karakteristik harga saham, bagaimana hubungan inflasi, kurs dan suku bunga terhadap harga saham JII. Pengetahuan yang ditemukan akan membantu investor untuk berinvestasi lebih cerdas. Jakarta Islamic Index (JII) adalah salah satu indeks saham yang menghitung indeks harga rata-rata saham untuk jenis saham yang memenuhi kriteria syariah. Pergerakan harga saham JII disajikan setiap hari berdasarkan harga penutupan di bursa efek pada hari tersebut. Data pergerakan saham terus bertambah dan menciptakan data yang besar atau gunungan data. Dalam gunungan data tersebut, tersembunyi pengetahuan dan informasi yang dapat ditemukan dengan menggunakan teknik data mining. Data mining merupakan sebuah teknologi baru yang powerful dengan potensi yang luar biasa untuk membantu institusi menemukan pengetahuan berharga di dalam database. Dalam penelitian ini data yang akan dianalisa adalah data pergerakan harga saham JII dan beberapa variabel ekonomi makro yang mempengaruhinya yang digunakan sebagai kriteria. Kemudian data tersebut akan dikelompokkan dengan menggunakan algoritma k-Means. Algoritma k-Means akan mengelompokkan objek-objek yang memiliki kemiripan ke dalam sebuah cluster. Cluster yang terbentuk merepresentasikan karakteristiknya masing-masing. Dalam penelitian ini ditemukan pengetahuan dari cluster yang terbentuk bahwa nilai suku bunga, kurs dan inflasi berbanding terbalik dengan harga saham.
\end{abstract}

Kata Kunci: Data Mining, Algoritma k-Means, Harga Saham

\section{PENDAhULUAN}

Kemampuan untuk memonitor harga pergerakan saham sangat diperlukan oleh investor. Seorang investor harus memahami pola prilaku harga saham di pasar modal. Tujuan investor berinvestasi di pasar modal tentunya ingin mendapatkan keuntungan yang maksimal. Berinvestasi di pasar modal membutuhkan pengetahuan finansial dan beberapa informasi untuk membantu para investor dalam pengambilan keputusan.

(Prayitno, 2015) mengatakan pasar modal menjadi tempat pilihan para investor, karena banyak menawarkan kerjasama dalam penyertaan modal dengan membeli saham, dimana emiten memberikan harapan keuntungan yang cukup besar dari pertumbuhan usaha yang sedang berjalan.

Jakarta Islamic Index (JII) menggambarkan rangkaian informasi historis mengenai pergerakan harga saham, sampai pada tanggal tertentu. Biasanya pergerakan saham tersebut disajikan setiap hari berdasarkan harga penutupan di bursa efek pada hari tersebut. Pencatatan harga saham setiap hari, dan setiap hari terus bertambah akan menciptakan gunungan data.

Dalam gunungan data tersebut, tersembunyi pengetahuan yang berpotensi untuk digali dengan menggunakan teknik data mining. Data mining merupakan sebuah teknologi baru yang powerful dengan potensi yang luar biasa untuk membantu institusi menemukan pengetahuan berharga di dalam database. Data mining merupakan tahapan yang esensial dalam proses penemuan pengetahuan (Condrobimo, Sano an Nindito, 2016). Pengetahuan yang ditemukan diharapkan mampu membantu investor untuk mengambil keputusan dalam berinvestasi di pasar modal.

Dalam penelitian ini data yang akan dianalisa adalah data pergerakan harga saham JII dan beberapa variabel ekonomi makro yang mempengaruhinya yang digunakan sebagai kriteria. Kemudian data tersebut akan dikelompokkan dengan menggunakan salah satu algoritma data mining yaitu algoritma k-Means.

Algoritma k-Means adalah algoritma terbaik, sederhana dan lebih cepat dibandingkan dengan algoritma clustering lainnya, karena itu algoritma kMeans lebih cocok dan sesuai untuk mengektraksi data pasar modal (Suganthi dan Kamalakannan, 2015).

Kuo-Ping. Yung-Piao. dan Lee (2014), sebelumnya juga menggunakan algoritma k-Means dan beberapa algoritma data mining lainnya, untuk memprediksi kecendrungan harga saham. Selain itu, Momeni, Mohseni dan Soofi (2015) mengelompokkan perusahaan yang terindeks di pasar modal untuk mencari perusahaan 
yang profitable dan perusahaan yang memiliki kriteria high-performance, penelitian ini juga dengan memanfaatkan algoritma k-Means.

Algoritma k-Means akan mengelompokkan objekobjek yang memiliki kemiripan ke dalam sebuah cluster. Cluster yang terbentuk merepresentasikan karakteristiknya masing-masing.

Dari kelompok data atau objek yang terbentuk akan dianalisis bagaimana hubungan harga saham dengan variabel ekonomi yang dijadikan sebagai kriteria. Hubungan inilah yang akan menjadi acuan investor yang sangat dibutuhkan investor untuk mengambil keputusan apabila hendak berinvestasi di pasar modal.

\section{RUANG LINGKUP}

Dalam penelitian ini permasalahan mencakup:

1. Cakupan permasalahan.

Perusahaan-perusahaan yang tergabung di bursa efek biasanya akan menawarkan sahamnya kepada publik dengan tujuan memperoleh dana untuk meningkatkan modal. Hal ini juga menjadi kesempatan baik bagi investor untuk membeli saham yang ditawarkan emiten guna beriventasi untuk mendapatkan laba atau keuntungan. Sebelum berinvestasi seorang investor membutuhkan informasi untuk menganalisis pergerakan harga saham di masa depan dan perlu adanya analisis bagaimana kondisi perekonomian agar terhindar dari resiko yang besar. Penelitian ini bertujuan mengidentifikasi karakteristik harga saham dan hubungannya dengan kondisi perekonomian.

2. Batasan-batasan penelitian.

Penelitian ini mengidentifikasi karakteristik harga saham terhadap 3 variabel ekonomi makro, yaitu inflasi, kurs dan tingkat suku bunga.

3. Rencana hasil yang didapatkan.

Menemukan karakteristik harga saham JII dan bagaimana kondisi ekonomi makro pada saat harga saham naik dan turun. Lebih detailnya, bagaimana hubungan harga saham JII dengan inflasi, kurs dan tingkat suku bunga. Pengetahuan ini diharapkan mampu membantu investor dalam pengambilan keputusan guna berinvestasi di pasar modal. Pemahaman tentang pergerakan harga saham memungkinkan investor berinvestasi lebih cerdas dan tentunya bisa memilih resiko paling minimum.

\section{BAHAN DAN METODE}

Pada bagian ini akan diuraikan teori-teori yang berkaitan dengan penelitian dan juga metodologi penelitian ini.

\subsection{Knowledge Discovery in Database (KDD)}

Knowledge discovery in database adalah sebuah proses terorganisir untuk mengidentifikasi pola dan pengetahuan dalam kumpulan data yang besar.

Gambar 1 menunjukkan proses penemuan pola atau pengetahuan pada KDD (Erdisna, Mayola dan Vitriani, 2016). Proses tersebut merupakan urutan berulang dari langkah-langkah berikut :

1. Pembersihan data (cleaning) dan integritas data (integration). Proses ini digunakan untuk menghilangkan noise dan data yang tidak konsisten.
2. Seleksi dan transformasi data (selection and transformation). Menemukan data yang relevan dengan tujuan penemuan pengetahuan dan mentransformasi data ke dalam bentuk yang sesuai.

3. Penambangan data (data mining). Merupakan proses esensial untuk mengekstraksi data, mencari pola atau informasi menarik dalam data terpilih dengan menggunakan metode tertentu.

4. Evaluasi pola dan presentasi pengetahuan (evaluation and representasion). Proses ini digunakan untuk mengidentifikasi pola yang benarbenar menarik yang mewakili pengetahuan dan menyajikan pengetahuan tersebut dengan teknik representasi.

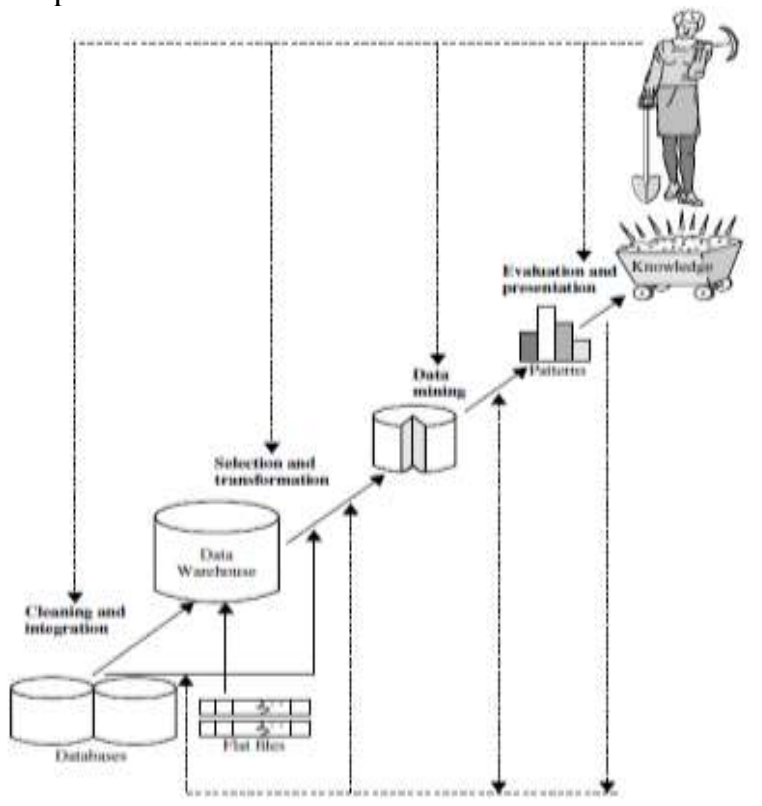

Gambar 1. Proses Knowledge Discovery

\subsection{Data Mining}

Data mining adalah salah proses penting dalam knowledge discovery in database dan dinyatakan sebagai sub-proses yang signifikan dalam manajemen pengetahuan (Silwattananusarn dan Kulthidatuamsuk, 2012).

Data mining merupakan sebuah proses untuk menemukan pola baru dari data yang besar (Murugan dkk, 2013).

Data mining adalah sebuah proses penganalisaan data untuk menemukan pola menarik dan pengetahuan (Bansal, 2017).

\subsection{Algoritma k-Means}

Algoritma k-Means termasuk dalam kelompok metode cluster analysis non-hirarki, di mana jumlah kelompok yang akan dibentuk sudah terlebih dahulu diketahui atau ditetapkan jumlahnya.

Algoritma k-Means cluster analysis menggunakan metode perhitungan jarak (distance) untuk mengukur tingkat kedekatan antara objek dengan titik tengah (centroid). Algoritma k-Means tidak terpengaruh terhadap urutan objek yang digunakan. Jumlah keanggotaan cluster yang dihasilkan berjumlah sama ketika menggunakan objek yang lain sebagai titik awal pusat cluster tersebut. Namun, hal ini hanya berpengaruh pada jumlah iterasi yang dilakukan. 
Algoritma k-Means ini dapat digunakan untuk meringkas objek dari jumlah besar sehingga lebih memudahkan untuk mendiskripsikan sifat-sifat atau karakteristik dari masing-masing kelompok. Algoritma k-Means akan digunakan untuk mengolah data pada penelitian ini.

Langkah-langkah dari k-Means clustering sangat sederhana. Diawali dengan menentukan jumlah cluster $k$, kemudian menginisialisasi centroid atau pusat cluster, dimana pusat cluster bisa ditentukan secara random. Setelah itu, algoritma k-Means akan menentukan koordinat centroid dan menghitung jarak tiap objek ke pusat cluster. Untuk menghitung jarak semua objek ke setiap titik pusat cluster dapat menggunakan teori jarak Euclidean Distance yang dirumuskan (1) sebagai berikut, (Ong, 2013):

$$
D_{i, j}=\sqrt{\left(x_{i}-s_{i}\right)^{2}+\left(x_{j}-s_{j}\right)^{2}}
$$

Di mana :

$$
\begin{array}{ll}
D_{i j} & : \text { Jarak objek antara objek } i \text { dan } j \\
x i, j & : \text { Pusat cluster } \\
s i, j & : \text { Objek } i \text { atau } j
\end{array}
$$

Setelah itu algoritma k-Means akan mengelompokkan objek berdasarkan jarak terdekat ke pusat cluster. Jika pusat cluster tidak berubah lagi maka proses clustering selesai.

\subsection{Metodologi Penelitian}

Kerangka kerja penelitian ini dapat dilihat pada gambar 2 ..

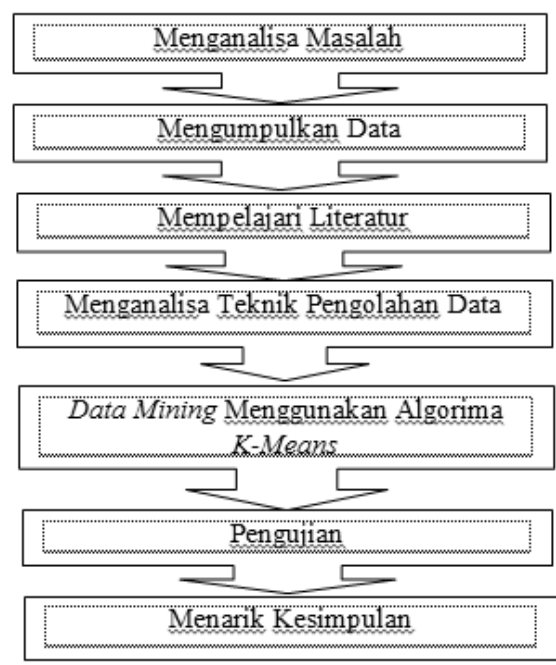

Gambar 2. Kerangka Penelitian

Berdasarkan kerangka kerja pada gambar 2, maka masing-masing langkahnya dapat diuraikan sebagai berikut :

\section{Menganalisa Masalah}

Pada tahap ini penulis melakukan analisa terhadap permasalahan dan cakupannya yang akan dibahas untuk mengidentifikasi karakteristik Jakarta Islamic Index (JII).
2. Mengumpulkan Data

Data yang diperlukan dalam penelitian ini adalah data histori JII, tingkat suku bunga, kurs dan inflasi.

3. Mempelajari Literatur

Untuk mencapai tujuan penelitian, maka dipelajari beberapa literatur yang diperkirakan dapat digunakan untuk penyelesaian masalah penelitian.

4. Menganalisa Teknik Pengolahan Data Memahami bagaimana proses algoritma k-Means untuk mengidentifikasi karakteristik saham JII.

5. Data Mining Menggunakan Algorima k-Means Tahap ini merupakan tahap inti dari penelitian ini, yaitu pengektrasian data, mencari pola atau informasi menarik dalam data histori saham JII dengan menggunakan Algoritma k-Means. Algoritma k-Means digunakan untuk mengelompokkan data harga saham JII. Kelompok data yang terbentuk merepresentasikan karakteristiknya masing-masing.

6. Pengujian

Sebuah Software Data Mining yaitu Rapid Miner digunakan untuk menguji hasil pengelompokan data saham JII dan memastikan keakuratan hasil ekstrasi data pada tahap ke 5 .

7. Menarik Kesimpulan

Setelah dilakukan pengujian, penulis akan menarik kesimpulan dari kelompok data yang terbentuk hasil clustering dengan algoritma k-Means.

\section{PEMBAHASAN}

Pada bagian ini akan diuraikan analisa data dan metode yang digunakan untuk menyelesaikan permasalahan penelitian.

\subsection{Analisa}

Penelitian ini fokus mengidentifikasi karakteristik harga saham JII terhadap inflasi, kurs dan tingkat suku bunga. Data yang digunakan adalah data Jakarta Islamic Index tahun 2015, 2016 dan 2017.

Harga saham akan dikelompokkan menjadi dua kelompok yaitu harga saham naik dan harga saham turun. Data dapat dilihat pada tabel 1 .

Tabel 1. Data Historis Pergerakan Saham Jakarta Islamic Index, Tingkat Suku Bunga, Kurs dan Inflasi

\begin{tabular}{|c|c|c|c|c|c|}
\hline No & Bulan & $\begin{array}{c}\text { Jakarta } \\
\text { Islamic } \\
\text { Index }\end{array}$ & $\begin{array}{c}\text { Tingkat } \\
\text { Suku } \\
\text { Bunga }\end{array}$ & Kurs & Inflasi \\
\hline 1 & $01 / 01 / 2015$ & 694,47 & 0,08 & 12516,24 & 0,06 \\
\hline 2 & $01 / 02 / 2015$ & 701,49 & 0,08 & 12686,16 & 0,06 \\
\hline 3 & $01 / 03 / 2015$ & 728,61 & 0,08 & 13001,55 & 0,06 \\
\hline 4 & $01 / 04 / 2015$ & 718,58 & 0,08 & 12882,90 & 0,07 \\
\hline 5 & $01 / 05 / 2015$ & 679,16 & 0,08 & 13074,79 & 0,07 \\
\hline 6 & $01 / 06 / 2015$ & 700,65 & 0,08 & 13246,52 & 0,07 \\
\hline 7 & $01 / 07 / 2015$ & 654,80 & 0,08 & 13307,79 & 0,07 \\
\hline 8 & $01 / 08 / 2015$ & 636,98 & 0,08 & 13712,80 & 0,07 \\
\hline 9 & $01 / 09 / 2015$ & 584,09 & 0,08 & 14324,19 & 0,07 \\
\hline 10 & $01 / 10 / 2015$ & 563,06 & 0,08 & 13726,95 & 0,06 \\
\hline 11 & $01 / 11 / 2015$ & 593,58 & 0,08 & 13604,19 & 0,05 \\
\hline 12 & $01 / 12 / 2015$ & 598,02 & 0,08 & 13785,45 & 0,03 \\
\hline 13 & $01 / 01 / 2016$ & 592,10 & 0,73 & 13819,75 & 0,04 \\
\hline
\end{tabular}




\begin{tabular}{|l|l|l|l|l|l|}
14 & $01 / 02 / 2016$ & 611,10 & 0,07 & 13448,20 & 0,04 \\
\hline 15 & $01 / 03 / 2016$ & 648,92 & 0,07 & 13127,14 & 0,04 \\
\hline 16 & $01 / 04 / 2016$ & 657,01 & 0,07 & 13113,90 & 0,04 \\
\hline 17 & $01 / 05 / 2016$ & 645,60 & 0,07 & 13352,60 & 0,03 \\
\hline 18 & $01 / 06 / 2016$ & 654,66 & 0,07 & 13288,41 & 0,03 \\
\hline 19 & $01 / 07 / 2016$ & 686,84 & 0,07 & 13053,12 & 0,03 \\
\hline 20 & $01 / 08 / 2016$ & 750,98 & 0,05 & 13099,09 & 0,03 \\
\hline 21 & $01 / 09 / 2016$ & 737,05 & 0,05 & 13052,71 & 0,03 \\
\hline 22 & $01 / 10 / 2016$ & 756,59 & 0,05 & 12952,24 & 0,03 \\
\hline 23 & $01 / 11 / 2016$ & 737,20 & 0,05 & 13243,95 & 0,04 \\
\hline 24 & $01 / 12 / 2016$ & 695,96 & 0,05 & 13350,57 & 0,03 \\
\hline 25 & $01 / 01 / 2017$ & 691,52 & 0,05 & 13291,76 & 0,03 \\
\hline 26 & $01 / 02 / 2017$ & 696,28 & 0,05 & 13273,84 & 0,04 \\
\hline 27 & $01 / 03 / 2017$ & 694,03 & 0,05 & 13278,50 & 0,04 \\
\hline 28 & $01 / 04 / 2017$ & 726,58 & 0,05 & 13239,89 & 0,04 \\
\hline 29 & $01 / 05 / 2017$ & 736,19 & 0,05 & 13256,60 & 0,04 \\
\hline 30 & $01 / 06 / 2017$ & 737,01 & 0,05 & 13231,88 & 0,04 \\
\hline 31 & $01 / 07 / 2017$ & 764,63 & 0,05 & 13275,10 & 0,04 \\
\hline 32 & $01 / 08 / 2017$ & 746,61 & 0,05 & 13274,82 & 0,04 \\
\hline 33 & $01 / 09 / 2017$ & 740,24 & 0,04 & 13236,95 & 0,04 \\
\hline 34 & $01 / 10 / 2017$ & 738,21 & 0,04 & 13458,32 & 0,04 \\
\hline 35 & $01 / 11 / 2017$ & 729,94 & 0,04 & 13459,36 & 0,03 \\
\hline
\end{tabular}

Proses clustering dengan menggunakan algoritma kMeans.

1. Menentukan jumlah cluster

Jumlah cluster yang ditentukan adalah 2 cluster, yaitu harga saham naik dan harga saham turun.

2. Menentukan centroid

Pusat awal cluster atau centroid sebagai berikut :

C1 $(563,06 ; 0,08 ; 13726,95 ; 0,06)$

C2 $(764,63 ; 0,05 ; 13275,10 ; 0,04)$

3. Menghitung jarak objek dari centroid

Menghitung jarak antara titik centroid dengan titik tiap objek dengan menggunakan Euclidian Distance kemudian mengalokasikan masing-masing objek ke centroid terdekat. Hasil perhitungan jarak dan pengelompokkan data iterasi 1 dapat dilihat pada Tabel 2.

Tabel 2. Hasil Perhitungan Jarak dan Pengelompokkan Data Iterasi 1

\begin{tabular}{|r|c|c|c|}
\hline DC1 & DC 2 & C1 & C2 \\
\hline 1217,82 & 762,096 & 0 & 1 \\
\hline 1049,96 & 592,315 & 0 & 1 \\
\hline 744,051 & 275,911 & 0 & 1 \\
\hline 858,258 & 394,894 & 0 & 1 \\
\hline 662,414 & 217,783 & 0 & 1 \\
\hline 499,744 & 70,0732 & 0 & 1 \\
\hline 429,082 & 114,592 & 0 & 1 \\
\hline 75,2621 & 455,934 & 1 & 0 \\
\hline 597,61 & 1064,51 & 1 & 0 \\
\hline 0 & 494,772 & 1 & 0 \\
\hline 126,497 & 370,889 & 1 & 0 \\
\hline 68,1502 & 536,858 & 1 & 0 \\
\hline 97,2398 & 571,324 & 1 & 0 \\
\hline 282,86 & 231,374 & 0 & 1 \\
\hline 605,924 & 187,832 & 0 & 1 \\
\hline 620,207 & 193,823 & 0 & 1 \\
\hline 383,342 & 142,037 & 0 & 1 \\
\hline 448,004 & 110,773 & 0 & 1 \\
\hline
\end{tabular}

\begin{tabular}{|r|r|l|l|}
685,105 & 235,216 & 0 & 1 \\
\hline 655,379 & 176,539 & 0 & 1 \\
\hline 696,328 & 224,094 & 0 & 1 \\
\hline 798,517 & 322,96 & 0 & 1 \\
\hline 513,433 & 41,5058 & 0 & 1 \\
\hline 399,155 & 102,036 & 0 & 1 \\
\hline 453,754 & 74,9842 & 0 & 1 \\
\hline 472,288 & 68,3616 & 0 & 1 \\
\hline 467,184 & 70,6818 & 0 & 1 \\
\hline 513,776 & 51,8416 & 0 & 1 \\
\hline 501,202 & 33,9276 & 0 & 1 \\
\hline 524,741 & 51,2916 & 0 & 1 \\
\hline 494,772 & 0 & 0 & 1 \\
\hline 487,967 & 18,0222 & 0 & 1 \\
\hline 521,05 & 45,2802 & 0 & 1 \\
\hline 320,686 & 185,115 & 0 & 1 \\
\hline 315,362 & 187,497 & 0 & 1 \\
\hline
\end{tabular}

Dari tabel 2 didapatkan anggota cluster baru sebagai berikut :

C1 : 8, 9, 10, 11, 12, 13 (Jumlah anggota : 6)

C2 : 1,2,3,4,5,6,7,14,15,16,17,18,19, 20,

$21,22,23,24,25,26,27,28,29,30,31,32$,

33, 34, 35 (Jumlah anggota : 29)

4. Melakukan iterasi berikutnya, kemudian menentukan posisi centroid baru dengan cara menghitung rata-rata dari data yang berada pada centroid yang sama. Centroid baru iterasi ke 1 dapat dilihat pada Tabel 3 .

Tabel 3. Centroid Baru Iterasi Ke 1

\begin{tabular}{|c|c|c|c|}
\hline $\begin{array}{c}\text { Jakarta } \\
\text { Islamic Index }\end{array}$ & $\begin{array}{c}\text { Tingkat Suku } \\
\text { Bunga }\end{array}$ & Kurs & Inflasi \\
\hline 594,64 & 0,18 & 13828,89 & 0,05 \\
\hline 705,55 & 0,06 & 13175,00 & 0,04 \\
\hline
\end{tabular}

5. Perulangan langkah ke-3 dilakukan, hingga posisi data tidak mengalami perubahan. Tabel 4 di bawah ini merupakan hasil perhitungan jarak dan pengelompokkan data iterasi ke 2 .

Tabel 4. Hasil Perhitungan Jarak dan Pengelompokkan Data Iterasi Ke 2

\begin{tabular}{|r|c|c|c|}
\hline \multicolumn{1}{|c|}{ DC1 } & DC 2 & C1 & C2 \\
\hline 1217,82 & 762,096 & 0 & 1 \\
\hline 1049,96 & 592,315 & 0 & 1 \\
\hline 744,051 & 275,911 & 0 & 1 \\
\hline 858,258 & 394,894 & 0 & 1 \\
\hline 662,414 & 217,783 & 0 & 1 \\
\hline 499,744 & 70,0732 & 0 & 1 \\
\hline 429,082 & 114,592 & 0 & 1 \\
\hline 75,2621 & 455,934 & 1 & 0 \\
\hline 597,61 & 1064,51 & 1 & 0 \\
\hline 0 & 494,772 & 1 & 0 \\
\hline 126,497 & 370,889 & 1 & 0 \\
\hline 68,1502 & 536,858 & 1 & 0 \\
\hline 97,2398 & 571,324 & 1 & 0 \\
\hline 282,86 & 231,374 & 0 & 1 \\
\hline 605,924 & 187,832 & 0 & 1 \\
\hline 620,207 & 193,823 & 0 & 1 \\
\hline
\end{tabular}




\begin{tabular}{|r|r|l|l|}
383,342 & 142,037 & 0 & 1 \\
\hline 448,004 & 110,773 & 0 & 1 \\
\hline 685,105 & 235,216 & 0 & 1 \\
\hline 655,379 & 176,539 & 0 & 1 \\
\hline 696,328 & 224,094 & 0 & 1 \\
\hline 798,517 & 322,96 & 0 & 1 \\
\hline 513,433 & 41,5058 & 0 & 1 \\
\hline 399,155 & 102,036 & 0 & 1 \\
\hline 453,754 & 74,9842 & 0 & 1 \\
\hline 472,288 & 68,3616 & 0 & 1 \\
\hline 467,184 & 70,6818 & 0 & 1 \\
\hline 513,776 & 51,8416 & 0 & 1 \\
\hline 501,202 & 33,9276 & 0 & 1 \\
\hline 524,741 & 51,2916 & 0 & 1 \\
\hline 494,772 & 0 & 0 & 1 \\
\hline 487,967 & 18,0222 & 0 & 1 \\
\hline 521,05 & 45,2802 & 0 & 1 \\
\hline 320,686 & 185,115 & 0 & 1 \\
\hline 315,362 & 187,497 & 0 & 1 \\
\hline
\end{tabular}

Dari tabel 4 didapatkan anggota cluster baru sebagai berikut :

$$
\begin{aligned}
\text { C1 }: & 8,9,10,11,12,13 \\
& \text { (Jumlah Anggota : 6) } \\
\text { C2 : } & 1,2,3,4,5,6,7,14,15,16,17,18,19,20, \\
& 21,22,23,24,25,26,27,28,29,30, \\
& 31,32,33,34,35 \\
& \text { (Jumlah Anggota : 29) }
\end{aligned}
$$

Pada iterasi ke 2 perulangan dihentikan karena hasil iterasi ke 1 dan iterasi ke 2 sudah tetap. Pada tabel 2 dan tabel 4 dapat dilihat bahwa posisi anggota cluster tetap.

Anggota masing-masing cluster dari data JII dapat dilihat pada tabel 5 dan tabel 6 .

\section{Tabel 5. Cluster 1 - Kelompok Harga Saham Turun}

\begin{tabular}{|l|l|l|l|l|l|}
\hline No & Bulan & $\begin{array}{c}\text { Jakarta } \\
\text { Islamic } \\
\text { Index }\end{array}$ & $\begin{array}{c}\text { Tingkat } \\
\text { Suku } \\
\text { Bunga }\end{array}$ & Kurs & Inflasi \\
\hline 8 & $01 / 08 / 2015$ & 636,98 & 0,08 & 13712,8 & 0,07 \\
\hline 9 & $01 / 09 / 2015$ & 584,09 & 0,08 & 14324,19 & 0,07 \\
\hline 10 & $01 / 10 / 2015$ & 563,06 & 0,08 & 13726,95 & 0,06 \\
\hline 11 & $01 / 11 / 2015$ & 593,58 & 0,08 & 13604,19 & 0,05 \\
\hline 12 & $01 / 12 / 2015$ & 598,02 & 0,08 & 13785,45 & 0,03 \\
\hline 13 & $01 / 01 / 2016$ & 592,1 & 0,73 & 13819,75 & 0,04 \\
\hline \multicolumn{2}{|l|}{ Cluster Centroid } & 594,64 & 0,18 & 13828,89 & 0,05 \\
\hline
\end{tabular}

Tabel 5 merupakan cluster 1, dibaca dari cluster centroid, cluster ini merepresentasikan harga saham turun yang memiliki karakteristik ; tingkat suku bunga, kurs dan inflasi tinggi. Nilai suku bunga, kurs dan inflasi pada cluster ini lebih tinggi dibandingkan dengan clustercentroid pada tabel 6 .

Tabel 6. Cluster 2 - Kelompok Harga Saham Naik

\begin{tabular}{|l|l|c|c|c|c|}
\hline No & Bulan & $\begin{array}{c}\text { Jakarta } \\
\text { Islamic } \\
\text { Index }\end{array}$ & $\begin{array}{c}\text { Tingkat } \\
\text { Suku } \\
\text { Bunga }\end{array}$ & Kurs & Inflasi \\
\hline
\end{tabular}

\begin{tabular}{|l|l|l|l|l|l|}
\hline 1 & $01 / 01 / 2015$ & 694,47 & 0,08 & 12516,24 & 0,06 \\
\hline 2 & $01 / 02 / 2015$ & 701,49 & 0,08 & 12686,16 & 0,06 \\
\hline 3 & $01 / 03 / 2015$ & 728,61 & 0,08 & 13001,55 & 0,06 \\
\hline 4 & $01 / 04 / 2015$ & 718,58 & 0,08 & 12882,90 & 0,07 \\
\hline 5 & $01 / 05 / 2015$ & 679,16 & 0,08 & 13074,79 & 0,07 \\
\hline 6 & $01 / 06 / 2015$ & 700,65 & 0,08 & 13246,52 & 0,07 \\
\hline 7 & $01 / 07 / 2015$ & 654,80 & 0,08 & 13307,79 & 0,07 \\
\hline 14 & $01 / 02 / 2016$ & 611,10 & 0,07 & 13448,20 & 0,04 \\
\hline 15 & $01 / 03 / 2016$ & 648,92 & 0,07 & 13127,14 & 0,04 \\
\hline 16 & $01 / 04 / 2016$ & 657,01 & 0,07 & 13113,90 & 0,04 \\
\hline 17 & $01 / 05 / 2016$ & 645,60 & 0,07 & 13352,60 & 0,03 \\
\hline 18 & $01 / 06 / 2016$ & 654,66 & 0,07 & 13288,41 & 0,03 \\
\hline 19 & $01 / 07 / 2016$ & 686,84 & 0,07 & 13053,12 & 0,03 \\
\hline 20 & $01 / 08 / 2016$ & 750,98 & 0,05 & 13099,09 & 0,03 \\
\hline 21 & $01 / 09 / 2016$ & 737,05 & 0,05 & 13052,71 & 0,03 \\
\hline 22 & $01 / 10 / 2016$ & 756,59 & 0,05 & 12952,24 & 0,03 \\
\hline 23 & $01 / 11 / 2016$ & 737,20 & 0,05 & 13243,95 & 0,04 \\
\hline 24 & $01 / 12 / 2016$ & 695,96 & 0,05 & 13350,57 & 0,03 \\
\hline 25 & $01 / 01 / 2017$ & 691,52 & 0,05 & 13291,76 & 0,03 \\
\hline 26 & $01 / 02 / 2017$ & 696,28 & 0,05 & 13273,84 & 0,04 \\
\hline 27 & $01 / 03 / 2017$ & 694,03 & 0,05 & 13278,50 & 0,04 \\
\hline 28 & $01 / 04 / 2017$ & 726,58 & 0,05 & 13239,89 & 0,04 \\
\hline 29 & $01 / 05 / 2017$ & 736,19 & 0,05 & 13256,60 & 0,04 \\
\hline 30 & $01 / 06 / 2017$ & 737,01 & 0,05 & 13231,88 & 0,04 \\
\hline 31 & $01 / 07 / 2017$ & 764,63 & 0,05 & 13275,10 & 0,04 \\
\hline 32 & $01 / 08 / 2017$ & 746,61 & 0,05 & 13274,82 & 0,04 \\
\hline 33 & $01 / 09 / 2017$ & 740,24 & 0,04 & 13236,95 & 0,04 \\
\hline 34 & $01 / 10 / 2017$ & 738,21 & 0,04 & 13458,32 & 0,04 \\
\hline 35 & $01 / 11 / 2017$ & 729,94 & 0,04 & 13459,36 & 0,03 \\
\hline ClusterCentroid & 705,55 & 0,06 & 13175,00 & 0,04 \\
\hline
\end{tabular}

Tabel 6 merupakan cluster 2, dibaca dari cluster centroid, cluster ini merepresentasikan harga saham naik yang memiliki karakteristik ; tingkat suku bunga, kurs dan inflasi rendah. Nilai suku bunga, kurs dan inflasi pada cluster ini lebih rendah dibandingkan dengan cluster centroid pada tabel 5.

\subsection{Hasil Pengujian dengan Menggunakan Rapid Miner}

Tabel 7 centroid cluster merupakan hasil eksekusi pengolahan data dengan menggunakan Software Rapid Miner. Dimana di tabel 5 dan tabel 6 mempunyai nilai centroid cluster yang sama dengan hasil pengujian pada Rapid Miner pada tabel 7 berikut ini.

Tabel 7. Centroid Cluster

\begin{tabular}{|l|l|l|}
\hline \multicolumn{1}{|c|}{ Attribute } & Cluster 1 & Cluster 2 \\
\hline JJI & 594.638 & 705.549 \\
\hline
\end{tabular}




\begin{tabular}{|l|l|l|} 
Tingkat Suku Bunga & 0.183 & 0.058 \\
\hline Kurs & 13828888 & 13174997 \\
\hline Inflasi & 0.054 & 0.044 \\
\hline
\end{tabular}

Dari centroid tabel 7 dapat dibaca :

Cluster 1- mempresentasikan penurunan harga saham, dengan karakteristik ; nilai suku bunga, kurs dan inflasi naik.

Sedangkan cluster 2 - mempresentasikan kenaikan harga saham, dengan karakteristik nilai suku bunga, kurs dan inflasi turun.

Dari 2 cluster ini dapat diidentifikasi bahwa nilai suku bunga, kurs dan inflasi berbanding terbalik dengan harga saham.

\section{KESIMPULAN}

Berdasarkan uraian yang sudah dikemukakan, maka dapat ditarik kesimpulan bahwa ditemukan pengetahuan berupa adanya perbedaan karakteristik yang kontradiktif antara harga saham naik dan harga saham turun. Jika harga saham naik, maka inflasi, kurs dan tingkat suku bunga turun. Sedangkan jika harga saham turun, maka inflasi, kurs dan tingkat suku bunga naik. Inflasi, kurs dan tingkat suku bunga berpengaruh signifikan terhadap harga saham. Artinya investor harus memperhatikan 3 variabel ini jika hendak berinvestasi di pasar modal. Pengetahuan inilah yang dibutuhkan investor sebagai acuan untuk berinvestasi.

\section{SARAN}

Untuk penelitian selanjutnya pengelompokkan data saham dan variabel ekonomi yang mempengaruhinya disarankan dengan jumlah data yang lebih besar dan variabel ekonomi yang lebih beragam sehingga pola yang ditemukan dapat menjawab semua permasalahan yang berhubungan dengan pengetahuan finansial yang dibutuhkan investor untuk pengambilan keputusan dalam beriventasi di pasar modal.

\section{DAFTAR PUSTAKA}

Bansal, A., Sharma, M., \& Goel, S. 2017. Improved KMean Clustering Algorithm for Prediction Analysis using Classification Technique in Data Mining. International Journal of Computer Applications, 157(6), 0975-8887.

Condrobimo, A. Raharto, Sano, Albert V Dian dan Nindito, Hendro. 2016. The Application of KMeans Algorithm for LQ45 Index on Indonesia Stock Exchange. ComTech, Vol. 7 No 2. June 2016. 151-159.

Erdisna, Mayola dan Vitriani. 2016. Data Mining's Clustering To Find Rainfall Characteristic Using KMeans Algorithm. ASEAN Comparative Education Research Network Conference.

Momeni, Mansoor., Mohseni \&, Soofi. 2015. Clustering Stock Market Companies Via K-Means Algorithm. Kuwait Chapter of Arabian Journal of Business and Management Review Vol. 4, No.5; January. 2015, 20(1), 22-29.

Murugan, K, dkk. 2013. Data Mining Using Integration of Clustering and Decision Tree, International Journal of Recent Advances in Engineering \&
Technology (IJRAET). ISSN (Online): 2347 2812, Volume-1, Issue -2.

Ong, Johan Oscar. 2013. Implementasi Algoritma KMeans Clustering Untuk Menentukan Strategi Marketing President University. Jurnal Ilmiah Teknik Industri, Vol. 12. No. 1.

Prayitno, Deden. 2015. Penerapan Association Rule Mining Pada Data Bursa Efek Indonesia Dengan Algoritma Apriori Untuk Memilih Saham Unggulan, Jurnal Teknologi, Volume 8 Nomor 2.

Silwattananusarn, Tipawan and Kulthida. 2012. Data Mining and Its Applications for Knowledge Management : A Literature Review from 2007 to 2012, International Journal of Data Mining \& Knowledge Management Process (IJDKP) Vol.2, No.5.

Suganthi, R. Dan Kamalakannan, P. 2015. Analyzing Stock Market Data Using Clustering Algoritm. International Journal of Future Computer and Communication, Vol. 4, No 2, April 2018, 108-111.

Wu, K.P., Wu, Y.P. and Lee, H.M. 2014. Stock Trend Prediction by Using K-Means and Apriori All Algorithm for Sequential Chart Pattern Mining. Journal of Information Science and Engineering. 30 (3), 653-667. 